\title{
Outer Membrane Protein Pattern of Eubacterium plautii
}

\author{
By ROALD BAARDSEN, ${ }^{1}$ VIDAR BAKKEN, ${ }^{1}$ HARALD B. JENSEN ${ }^{1}$ AND \\ TOR HOFSTAD ${ }^{2 *}$ \\ ${ }^{1}$ Department of Biochemistry and ${ }^{2}$ Department of Microbiology and Immunology, \\ The Gade Institute, University of Bergen, 5021 Bergen, Norway
}

(Received 4 December 1987)

The outer membrane SDS-PAGE pattern of Eubacterium plautii was characterized by a large number of surface exposed low- and high-molecular-mass proteins. Silver stainable carbohydrate was not present. The pattern was clearly distinct from those of outer membrane preparations of Eubacterium saburreum and Fusobacterium nucleatum. The results are compatible with a Gram-positive cell wall structure in $E$. plautii.

\section{INTRODUCTION}

Eubacterium plautii is an anaerobic rod that stains Gram-negative. A morphological description of the organism was given by Plaut (1907). Sèguin (1928), who succeeded in isolating the organism in pure culture, named it Fusobacterium plauti (sic). Jantzen \& Hofstad (1981) found that the fatty acid pattern of the organism differed markedly from those of Fusobacterium species. 3-Hydroxy fatty acids, which are invariably present in Gram-negative bacteria as constituents of the cell wall lipopolysaccharide, were absent. Electron microscopical examination showed that the organism had a homogeneous, thick outer layer, not the triplelayered outer membrane characteristic of a Gram-negative bacterium (Hofstad \& Aasjord, 1982). Based on these findings, Hofstad \& Aasjord (1982) proposed a transfer of the organism from the genus Fusobacterium to the genus Eubacterium as Eubacterium plautii (Sèguin) comb. nov.

The present report deals with SDS-PAGE profiles of outer membrane proteins in E. plautii as compared to those of Fusobacterium nucleatum and Eubacterium saburreum.

\section{METHODS}

Bacterial strains and growth conditions. E. plautii strains VPI 0310 (= ATCC 29863) and VPI 4145 were obtained from Department of Anaerobic Microbiology, Virginia Polytechnic Institute and State University, Blacksburg, Va., USA. F. nucleatum Fev 1 was provided by S. E. Mergenhagen, National Institute of Dental Research, Bethesda, Md., USA. E. saburreum strain L32 (Hofstad \& Skaug, 1978) was isolated from human saliva. The organisms were cultivated in a fluid medium based on tryptone and yeast extract, and supplemented with vitamin $\mathbf{B}_{12}$, haemin, menadion, glucose and (for the cultivation of strain L32) human plasma (Hofstad \& Aasjord, 1982). Ascorbic acid was used as the reducing agent. Bacteria were harvested in the late exponential phase of growth.

Preparation of membranes. Outer membrane fractions were prepared as described by Bakken \& Jensen (1986). The harvested cells were washed in cold $0.03 \mathrm{M}$ - Tris/ $\mathrm{HCl}, \mathrm{pH} 8 \cdot 1$, resuspended in the same buffer and broken by one passage through a French pressure cell at about $3000 \mathrm{lbf} \mathrm{in}^{-2}(20.7 \mathrm{MPa})$. After centrifugation at $2000 \mathrm{~g}$ for $5 \mathrm{~min}$ to remove unbroken cells (a very small pellet), the cell envelopes were sedimented by centrifugation at $10000 \mathrm{~g}$ for $15 \mathrm{~min}$ at $4{ }^{\circ} \mathrm{C}$. The envelope fraction was washed twice by resuspension in $10 \mathrm{mM}-\mathrm{HEPES}, 10 \mathrm{mM}$ $\mathrm{MgCl}_{2}$ buffer, adjusted to $\mathrm{pH} 7 \cdot 4$ with $\mathrm{NaOH}$, followed by centrifugation as above. Triton $\mathrm{X}-100$ was added to a concentration of $2 \%(\mathrm{v} / \mathrm{v})$ and the mixture incubated at room temperature for $20 \mathrm{~min}$. After centrifugation at $10000 \mathrm{~g}$ for $15 \mathrm{~min}$ at $4{ }^{\circ} \mathrm{C}$, the pellet, i.e. the outer membrane fraction, was washed twice in $10 \mathrm{mM}$-HEPES buffer containing $\mathrm{MgCl}_{2}$ as above. 


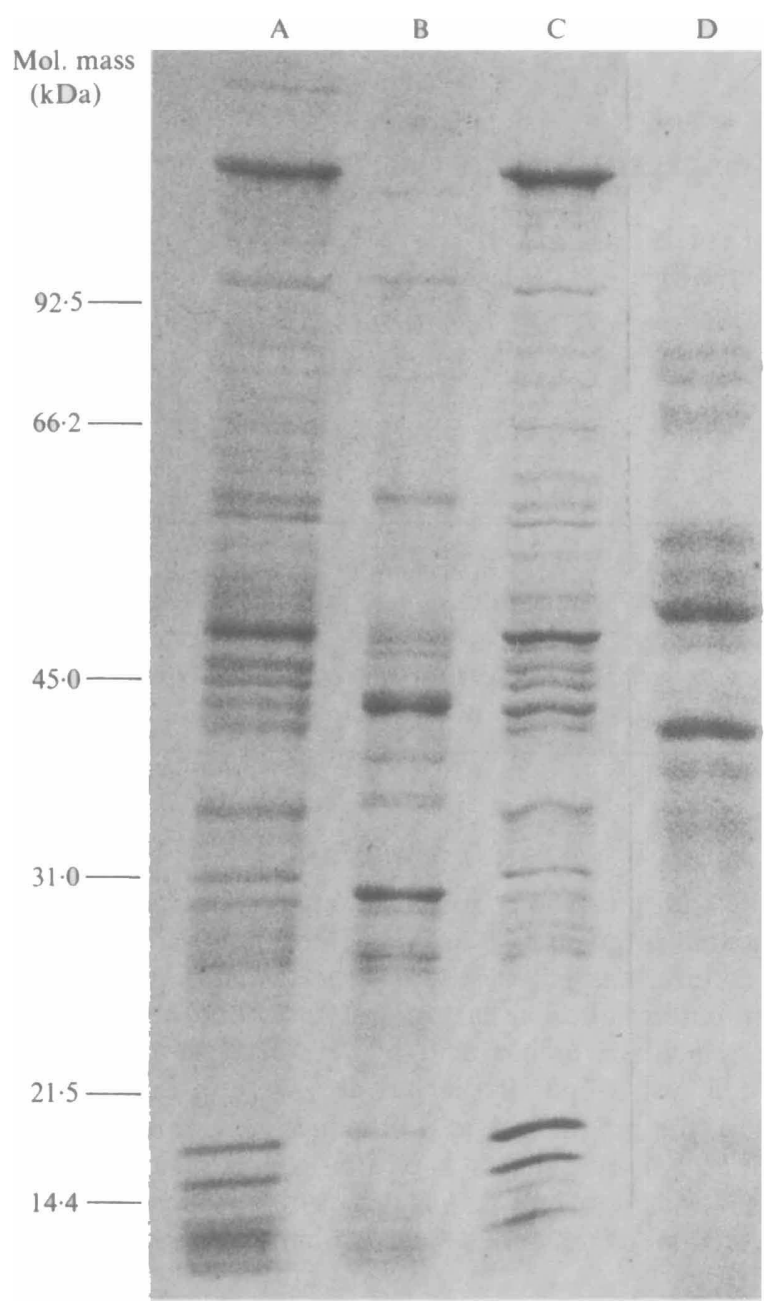

Fig. 1. SDS-PAGE profiles of Coomassie brilliant blue stained outer membrane proteins of $E$. plautii VPI 0310 (lane A), VPI 4145 (lane C), E. saburreum L32 (lane B) and F. nucleatum Fev 1 (lane D). Molecular mass standards are indicated on the left.

Radioiodination of bacteria. Labelling with ${ }^{125} \mathrm{I}$ was done according to the method of Marchalonis (1969). To $200 \mu \mathrm{l}$ cell suspension $\left(5 \times 10^{8}\right.$ cells $\left.\mathrm{ml}^{-1}\right)$ in $0.02 \mathrm{M}$-sodium phosphate buffer, $\mathrm{pH} 7 \cdot 1$, containing $0.9 \%(\mathrm{w} / \mathrm{v})$ $\mathrm{NaCl}$, was added $500 \mu \mathrm{Ci}(18.5 \mathrm{MBq}) \mathrm{Na}^{125} \mathrm{I}, 5 \mu \mathrm{g}$ lactoperoxidase and $8 \times 10^{-5} \mathrm{M}-\mathrm{H}_{2} \mathrm{O}_{2}$. The reaction was stopped after $10 \mathrm{~min}$ with $10 \mu \mathrm{l} 1 \mathrm{M}-2$-mercaptoethanol, followed by $800 \mu \mathrm{l}$ cell suspension. The cells were sedimented $(10000 \mathrm{~g}$ for $10 \mathrm{~min})$ and Triton X-100 insoluble cell envelope material was prepared as described above. After analysis by SDS-PAGE, the gels were laid onto Kodak X-Omat films for autoradiography. The films were scanned with a Zeineh scanning densitometer, soft laser $630 \mathrm{~nm}$, adjusting in each case the intensity of the most dense peak to about $80 \%$ of full scale.

SDS-PAGE. Membrane proteins were separated by SDS-PAGE according to the method of Laemmli (1970). The concentration of polyacrylamide in the separating gel was $15 \%(\mathrm{w} / \mathrm{v})$. The proteins were stacked in $4 \%$ polyacrylamide gel. Samples were heated in the sample buffer at $100{ }^{\circ} \mathrm{C}$ for $5 \mathrm{~min}$. Samples containing $10-30 \mu \mathrm{g}$ or 0.1-1 $\mu \mathrm{g}$ protein were applied to gels when they were stained with Coomassie brilliant blue R250 or silver, respectively. Silver staining was done according to Marshall \& Latner (1981), with the modifications that all steps were done at $50{ }^{\circ} \mathrm{C}$, using ammonia in the diamine step, and $2 \%(\mathrm{v} / \mathrm{v})$ glutaraldehyde. Bio-Rad low molecular mass protein standards were used as size markers.

Protein estimation. This was done by a modified Lowry method as outlined by Markwell et al. (1978). 


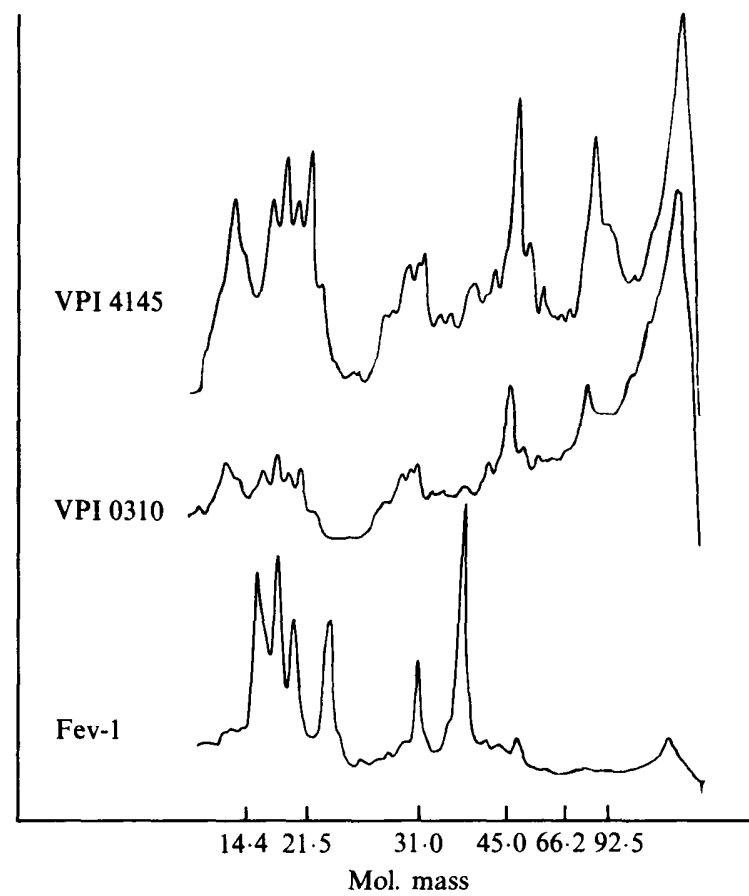

Fig. 2. Autoradiography scans of SDS-PAGE gels stained with Coomassie brilliant blue. Molecular masses are indicated at the bottom.

\section{RESULTS}

The SDS-PAGE patterns of the outer membrane fractions of E. plautii VPI 0310 and VPI 4145 were virtually identical (Fig. 1, lanes A and C). The pattern was distinct and reproducible, and was characterized by a rather large number of low- and high-molecular-mass proteins in large amounts. Similarly, the outer membrane fraction of $E$. saburreum L32 was resolved into a large number of proteins, but the pattern was quite distinct from that of VPI 0310 and VPI 4145 (Fig. 1, lane B). In contrast, the outer membrane protein pattern of $F$. nucleatum Fev 1 showed relatively few bands.

The protein patterns of the envelope fractions of the Eubacterium strains were strikingly similar to that of the outer membranes (not shown). In agreement with this the amount of protein in the Triton X-100 soluble fraction was very small. The envelope fraction of $F$. nucleatum Fev 1 had more heavily stained bands than did the outer membrane fraction. A substantial amount of the protein in the envelope fraction was soluble in Triton X-100 (see also Bakken \& Jensen, 1986).

Cell surface exposed proteins were compared by iodination of living cells. Following SDSPAGE and autoradiography scans of the profiles were compared. Fig. 2 shows the relative amounts of radioactivity and molecular masses of the proteins of the outer membrane fractions of VPI 0310 and VPI 4145 compared to Fev 1. Again the profiles of the E. plautii strains VPI 0310 and VPI 4145 were apparently identical and distinctly different from that of F. nucleatum Fev 1. Proteins soluble in Triton X-100 were not labelled and neither were the cytoplasmic proteins.

Lipopolysaccharides or other carbohydrate materials were looked for in SDS-PAGE gels stained with silver. $F$. nucleatum Fev 1 gave clear positive reactions, mainly in the lowmolecular-mass region, but also in the $50-70 \mathrm{kDa}$ region. Weak positive reactions were obtained with the L32 outer membrane preparation, whereas the outer membrane preparations of E. plautii VPI 0310 and VPI 4145 gave completely negative reactions. 


\section{DISCUSSION}

The similarity in outer membrane banding pattern and profiles of surface exposed proteins indicate a near clonal relationship between $E$. plautii VPI 0310 and VPI 4145 . In fact, they may be representatives of the same clone. The multitude of Triton X-100 insoluble proteins and the lack of silver stainable material in the outer membrane preparation is compatible with a Grampositive cell wall structure. In particular, the outer membranes of VPI 0310 and VPI 4145 contained no major protein in the $30-40 \mathrm{kDa}$ range, which is typical of Gram-negative bacteria. The results of this study are thus in agreement with the previous finding of a whole cell fatty acid pattern lacking 3-hydroxy fatty acids (Jantzen \& Hofstad, 1981).

The relationship of the proposed species E. plautii to other Eubacterium species may be questioned. E. plautii stains Gram-negative, and the outer membrane protein pattern is quite different from that of $E$. saburreum L32. Diaminopimelic acid (Dpm) was absent in peptidoglycan preparations from $E$. plautii VPI 4145, which contained several amino acids, among them lysine and aspartic acid (Vasstrand et al., 1982). In contrast, Eubacterium tenue (Weiss et al., 1981) and E. saburreum (O. Kandler, personal communication) have a directly cross-linked m-Dpm type of peptidoglycan. The LL-Dpm type is found in Eubacterium lentum and Eubacterium combesii (Weiss et al., 1983). The rare subgroup B2 $\alpha$ peptidoglycan is present in Eubacterium limosum (Schleifer \& Kandler, 1972). Obviously, the genus Eubacterium is heterogeneous.

\section{REFERENCES}

BaKken, V. \& Jensen, H. B. (1986). Outer membrane proteins of Fusobacterium nucleatum Fev 1. Journal of General Microbiology 132, 1069-1078.

Hofstad, T. \& Skaug, N. (1978). A polysaccharide antigen from the Gram-positive organism Eubacterium saburreum containing dideoxyhexose as the immunodominant sugar. Journal of General Microbiology 106, 227-232.

HOFSTAD, T. \& AASJORD, P. (1982). Eubacterium plautii (Sèguin 1928) comb. nov. International Journal of Systematic Bacteriology 32, 346-349.

JANTZEN, E. \& HoFstaD, T. (1981). Fatty acids of Fusobacterium species: taxonomic implications. Journal of General Microbiology 123, 163-171.

LAEMMLI, U. K. (1970). Cleavage of structural proteins during assembly of the head of bacteriophage T4. Nature, London 227, 680-685.

MaRCHalonis, J. J. (1969). An enzymatic method for trace iodination of immunoglobulins and other proteins. Biochemical Journal 113, 299-305.

Markwell, M. A. K., HaAs, S. M., Bieber, L. L. \& TOLBERT, N. E. (1978). A modification of the Lowry procedure to simplify protein determination in membrane and lipoprotein samples. Analytical Biochemistry 87, 206-210.
MARSHALL, T. \& LATNER, A. L. (1981). Incorporation of methylamine in an ultrasensitive silver stain for detecting proteins in thick polyacrylamide gels. Electrophoresis 2, 228-235.

Plaut, H. C. C. (1907). Über die Geisseln bei fusiformen Bacillen. Zentralblatt für Bakteriologie, Parasitenkunde und Infektionskrankheiten (Abteilung I, Originale A) 44, 310-316.

Schleifer, K. H. \& Kandler, O. (1972). Peptidoglycan types of bacterial cell walls and their taxonomic implications. Bacteriological Reviews 36, 407-477.

SÈGUIN, P. (1928). Culture du Fusobacterium plauti, forme mobile du Bacille fusiforme. Compte rendu de la Societé de biologie 99, 439-442.

Vasstrand, E. N., Jensen, H. B., Miron, T. \& HoFsTAD, T. (1982). Compositions of peptidoglycans in Bacteroidaceae. Determination and distribution of lanthionin. Infection and Immunity 36, 114-122.

WeIss, N., SchleIfER, K. H. \& KANDLER, O. (1981). The peptidoglycan types of Gram-positive anaerobic bacteria and their taxonomic implications. Revue de l'Institut Pasteur de Lyon 14, 3-12. 